EDITORIAL

\title{
Der Leukämieursache auf der Spur?
}

\author{
F. Lampert \\ Universitäts-Kinderpoliklinik Gießen
}

Nicht ohne Absicht beginnt dieses Heft mit einem Beitrag über den ,Mechanismus der virus-induzierten Leukämieentstehung“ (1) und endet mit einem Bericht über „Chromosomenveränderungen bei Leukämie", dem Thema der letztjährigen Kind-Philipp-Expertentagung in Bonn. In den letzten Jahren ist man tatsächlich den entscheidenden Vorgängen, die aus einer Normalzelle eine unkontrolliert wachsende, undifferenzierte „bösartige“ Zelle machen, ein Stück nähergekommen. Diese Annäherung geschah von 2 Seiten: einmal durch die Techniken der Molekularbiologie wie Gentransfer, Molekularklonierung und die Entdeckung der Retroviren (RNS-Viren mit ,onc-Genen“, d. h. umschriebenen Informationsbereichen ihrer Erbmasse, die Normalzellen in Krebszellen umwandeln können) (2); und das andere Mal durch verbesserte Methodik der Zytogenetik wie synchronisierte Zellkultur und Vielbänderung langgestreckter Chromosomen (5). Dabei ergab sich, daß im Mittelpunkt der malignen Transformation die DNA, die Desoxyribonukleinsäure, also das in der menschlichen diploiden Zelle in 46 Chromosomen verpackte riesenlange Kettenmolekül steht.

Das erstaunlichste Ergebnis der Molekularbiologen war, daß eine Punktmutation, die Veränderung eines einzigen $\mathrm{Nu}$ kleotids in einem Normalgen, genügte, um aus einem fest in der Zelle verankerten und konservierten ,Proto-Onkogen " ein aktives Onkogen zu machen, dessen Proteinprodukt die maligne Zelltransformation bewirkt und auf Dauer erhält (4). Das erstaunlichste Ergebnis der Leukämiezytogenetiker war die immer deutlicher werdende Spezifität von Chromosomenveränderungen für die einzelnen Leukämiearten, meist in Form von sogenannten reziproken Translokationen, wobei die Bruchstelle sowohl im Empfänger-, wie auch im Geberchromosom entscheidend sein kann (5). Es ist verlockend, die inzwischen bekannten Translokationen bei den verschiedenen Leukämien mit den inzwischen bekannten Chromosomenlokalisationen von zellulären Onkogenen in Beziehung zu setzen (Tab. 1) und zu spekulieren, daß die Aktivierung eines Onkogens durch einen Chromosomenbruch in einer Stammzelle mit anschließender Neugruppierung von Chromosomenmaterial zustande kommt (3).

Nun, wie auch die endgültige Ätiologie sein mag, eine Hilfe zumindestens schon für den Kliniker wird die konstant gefundene Chromosomenveränderung eines Leukämiezellklons sein, wird man hierbei doch neue Typen finden, die sich biologisch unterschiedlich verhalten. Bei den Chromosomenveränderungen der Leukämiezellen müssen allerdings streng unterschieden werden die ätiologisch wichtigen primären Störungen, also die spezifischen Translokationen, von den
Klin. Pädiat. 196 (1984) 123-124

(C) F. Enke Verlag Stuttgart

\section{Closing in on the: Cause of Leukemia?}

It is no coincidence that this journal edition begins with a contribution on the mechanism of virus-induced leukemogenesis (1) and ends with a report on ,chromosomal alterations in leukemia", which had been the theme of last year's Kind-Philipp expert's meeting in Bonn. Indeed, within the last few years, important advances have been made in the elucidation of mechanisms which transform a normal cell into a. wildly growing, undifferentiated ,malignant“ cell. The problem was attacked on two fronts. The first approach used techniques of molecular biology such as gene transfer and molecular cloning. The discovery of retroviruses (RNA tumor viruses with oncogenes, i.e. specific sequences in their genome which can transform a normal cell into a cancer cell in vitro) (2), was an important contribution. The second approach involves improved techniques of cytogenetics, such as synchronized cell culture and high-banding of stretched chromosomes (5).

DNA, deoxyribonusleic acid, the very long double-helical molecule packed into 46 chromosomes in the human diploid cell, was fourd to play the central role in malignant transformation.

The most fascinatirg result discovered by molecular biologists was the fact that a point mutation, i.e. an alteration within a single nucleotide of a normal gene, is sufficient to render a proto-oncogene, which normally rests dormant in the cell, into an active oncogene, whose protein product then causes and maintains malignant cell transformation (4). The most fascinating result discovered by leukemia cytogenetisists was the increasingly recognized specificity and consistency of chromosomal lesions in different leukemia subtypes. These lesions occur mostly as reciprocal translocations and the site of the chromatid break can be decisive in the receptor as well as in the donor chromosome (5).

It is tempting to relate hitherto known translocations found in different eukemias to the newly discovered chromosomal sites of cellular oncogenes (Table 1) and to speculate that activation of an oncogene might be induced by chromatid breakage in a stem cell with subsequent rearrangement of chromosomal material (3).

Be that as it may, the current state of our understanding can already offer help for the clinical routine. The consistently found chromosomal defects within leukemic cell clones allow characterization of individual leukemia subtypes. However primary and secondary chromosomal changes must be distinguished. Only primary karyotypic changes, i.e. specific translocations, are possibly related 
Tab. 1 Chromosomaler Sitz menschlicher zellulärer Onkogene und ihre mögliche Beziehung zu leukämiespezifischen Chromosomenveränderungen

\begin{tabular}{|c|c|c|c|c|}
\hline Onkogen & Chromosom & $\begin{array}{l}\text { Chromoso- } \\
\text { menverän- } \\
\text { derung }\end{array}$ & Bruchstelle & $\begin{array}{l}\text { Leukämie- } \\
\text { art }\end{array}$ \\
\hline$a b l$ & $9 q 34$ & $t(9 ; 22)$ & $\begin{array}{l}9 q 34.1 ; \\
22 q 11.21\end{array}$ & $\begin{array}{l}\text { CML } \\
A L L-L_{1}, L_{2}\end{array}$ \\
\hline mos & 8922 & $t(8 ; 21)$ & $\begin{array}{l}8 \mathrm{q} 22.1 \text {; } \\
21 \mathrm{q} 22.3\end{array}$ & $A N L L-M_{2}$ \\
\hline $\begin{array}{l}\text { fes } \\
\text { erb A }\end{array}$ & $\begin{array}{l}15 \text { (q24- } \\
q 25) \\
17(p 11- \\
q 21)\end{array}$ & $t(15 ; 17)$ & $\begin{array}{l}\text { 15q22; } \\
17 q 11.2\end{array}$ & ANLL $-M_{3}$ \\
\hline ref 2 & 4 & $t(4 ; 11)$ & $4 q 21 ; 11 q 23$ & $A L L-L_{2}$ \\
\hline myc & $8 q 24$ & $t(8 ; 14)$ & $\begin{array}{l}8 q 24.13 \\
14 q 32.33\end{array}$ & $\begin{array}{l}A L L-L_{3} \\
B L\end{array}$ \\
\hline
\end{tabular}

zelluläre Retrovirus-Onkogenhomologe: abl - Abelson murine leukemia virus; mos - Moloney murine sarcoma virus; fes - SnyderTheilin feline sarcoma virus; erb A - Avian erythroblastosis virus; raf - 3611 murine sarcoma virus (Ulff Rapp); myc - Avian myelocytomatosis virus.

$q=$ langer $; p=$ kurzer Chromosomenarm; $t=$ Translokation. CML = chronische myeloische Leukämie, ANLL = akute nichtIymphoblastische Leukämie, ALL = akute lymphoblastische Leukämie, $L_{2}, L_{3}=$ Subtypen der ALL nach der French-AmericanBritish-Klassifizierung, $M_{2}, M_{3}=$ Subtypen der $A N L L, B L=$ Burkitt's Lymphom.

klinisch wichtigeren sekundären Aberrationen, also einem Zuviel oder Zuwenig von Chromosomen oder Chromosomenmaterial, was wahrscheinlich entscheidend für Proliferation, Metastasierung und Ansprechen oder Resistenz gegenüber Therapie ist. Besonders bei der akuten lymphoblastischen Leukämie wird es schwierig sein, primäre von sekundären Chromosomenveränderungen zu trennen. Nichtsdestoweniger sollte zukünftig jedem Leukämieknochenmark von Patienten einer deutschen Therapiestudie die Chance einer Chromosomenuntersuchung bzw. DNS-Ploidieuntersuchung gegeben werden. Entsprechend eingerichtete Labors in Gießen (Universitäts-Kinderpoliklinik), Hamburg (II. Medizinische Universitätsklinik), München (UniversitätsKinderpoliklinik), Münster (DNS-Impulszytophotometrie: Medizinische Univ.-Klinik A, Universitäts-Kinderklinik) und Wien (St. Anna-Kinderspital) stehen bereit.

\section{Literatur}

1 Graf, $T$.: Uber den Mechanismus der virus-induzierten Leukämieentstehung in einem tierischen Modellsystem. Klin. Paed. 196 (1984)

2 Krontiris, T.G.: The emerging genetics of human cancer. New Engl. J. Med. 309 (1983) 404-409

3 Sandberg, A.A.: A chromosomal hypothesis of oncogenesis. Cancer Genet. Cytogenet. 8 (1983) 277-285

4 Weinberg, R.A.: Alteration of the genomes of tumor cells. Cancer 52 (1983) 1971-1975

5 Yunis, J.J.: The chromosomal basis of human neoplasia. Science 221 (1983) 227-236
Tab. 1 Chromosomal Position of Human Cellular Oncogenes and their Possible Relationship to Leukemia Specific Chromosomal Changes

\begin{tabular}{|c|c|c|c|c|}
\hline Oncogene & Chromosome & $\begin{array}{l}\text { Chromo- } \\
\text { somal } \\
\text { changes }\end{array}$ & $\begin{array}{l}\text { Breakage } \\
\text { point }\end{array}$ & $\begin{array}{l}\text { Leukemia } \\
\text { type }\end{array}$ \\
\hline$a b l$ & $9 q 34$ & $t(9 ; 22)$ & $\begin{array}{l}9 q 34.1: \\
22 q 11.21\end{array}$ & $\begin{array}{l}C M L \\
A L L-L_{1}, \\
L_{2}\end{array}$ \\
\hline mos & $8 q 22$ & $t(8 ; 21)$ & $\begin{array}{l}8 q 22.1 ; \\
21 q 22.3\end{array}$ & $\begin{array}{l}\text { ANLL - } \\
M_{2}\end{array}$ \\
\hline fes & $\begin{array}{l}15 \text { (q24- } \\
q 25)\end{array}$ & & & \\
\hline erb $A$ & $\begin{array}{l}17(p 11- \\
q 21)\end{array}$ & $t(15 ; 17)$ & $\begin{array}{l}\text { 15q22; } \\
17 q 11.2\end{array}$ & $\begin{array}{l}\text { ANLL - } \\
M_{3}\end{array}$ \\
\hline raf 2 & 4 & $t(4: 11)$ & $4 q 21 ; 11 q 23$ & $A L L-L_{2}$ \\
\hline myc & $8 q 24$ & $t(8 ; 14)$ & $\begin{array}{l}8 q 24.13 \\
14 q 32.33\end{array}$ & $\begin{array}{l}\text { ALL- } L_{3} \\
\text { BL }\end{array}$ \\
\hline
\end{tabular}

Retrovirus oncogene homologs: abl - Abelson murine leukemia virus; mos - Moloney murine sarcoma virus; fes - Snyder-Theilin feline sarcoma virus; erb A - Avian erythroblastosis virus; raf 3611 murine sarcoma virus (Ulff Rapp); myc - Avian myelocyto. matosis virus.

$q=$ long; $p=$ short chromosomal arm; $t=$ translocation

$\mathrm{CML}=$ Chronic myelocytic leukemis, $A N L L=$ acute non-lymphoblastic leukemia, $A L L=$ acute lymphoblastic leukemia, $L_{2}, L_{3}=$ Subtypes of ALL occording to the French-American-British Classification, $M_{2}, M_{3}=$ Subtypes of ANLL, BL = Burkitt's Lymphoma.

to etiology. Secondary changes, such as missing or extra chromosomes in the karyotype, are often variable and may reflect different biological behaviour. However, this is important for the estimation of sensitivity or resistance to therapy. In acute lymphoblastic leukemia, in particular, it will be difficult to differentiate between primary and secondary changes. Nevertheless, our future goals include chromosomal analysis of each leukemic bone marrow from a patient treated in a controlled German study.

Special laboratories in Gießen (Universitäts-Kinderpoliklinik), Hamburg (II. Medizinische Universitätsklinik), Munich (Universitäts-Kinderpoliklinik), Münster (DNA-Flowcytophotometry: Medizinische Universitätsklinik, Universitäts-Kinderklinik) and Vienna (St. Anna Kinderspital) are now in the position to undertake these specialized tests.

\section{References}

1 Graf, T.: Uber den Mechanismus der virus-induzierten Leukämieentstehung in einem tierischen Modellsystem. Klin. Paed. 196 (1984)

2 Krontiris, T.G.: The emerging genetics of human cancer. New Engl. J. Med. 309 (1983) 404-409

3 Sandberg, A.A.: A chromosomal hypothesis of oncogenesis. Cancer Genet. Cytogenet. 8 (1983) 277-285

4 Weinberg, R.A.: Alteration of the genomes of tumor cells. Cancer 52 (1983) $1971-1975$

5 Yunis, J.J.: The chromosomal basis of human neoplasia. Science 221 (1983) 227-236

Prof. Dr. med. F. Lampert, Universitäts-Kinderpoliklinik, Feulgenstraße 12, D-6300 Gießen 